\title{
ニコチン受容体を標的とした統合失調症治療薬の可能性
}

鴻海俊太郎, ${ }^{a, b}$ 末丸克矢, ${ }^{*, b}$ 川崎博己, ${ }^{a}$ 町支臣成, ${ }^{c}$ 日比野 $\quad$ 俐, ${ }^{c}$ 荒木博陽 $b$

\section{Nicotinic Acetylcholine Receptors are Possible Therapeutic Targets for Schizophrenia}

\author{
Shuntaro Kohnomi ${ }^{a, b}$ Katsuya Suemaru, ${ }^{*, b}$ Hiromu Kawasaki, ${ }^{a}$ Tominari Choshi, ${ }^{c}$ \\ Satoshi HiBINO, ${ }^{c}$ and Hiroaki ARAKI ${ }^{b}$ \\ ${ }^{a}$ Department of Clinical Pharmaceutical Science, Graduate School of Natural Science and Technology, \\ Okayama University, 1-1-1 Tsushima-naka, Okayama 700-8530, Japan, ${ }^{b}$ Department of Clinical \\ Pharmacology and Pharmacy, Ehime University Graduate School of Medicine, Shitsukawa, \\ Toon, Ehime 791-0295, Japan, and 'Faculty of Pharmacy and Pharmaceutical Science, \\ Fukuyama University, 1-3 Gakuen-cho, Fukuyama, Hiroshima 729-0292, Japan
}

(Received September 24, 2008)

\begin{abstract}
The rate of smoking in patients with schizophrenia is higher than that in the general population. Nicotinic acetylcholine receptors (nAChR) are involved in the sensorimotor gating deficits in schizophrenia. We have revealed that nicotine ameliorates the disruption of the PPI, a model of sensorimotor gating, which is induced by apomorphine, a dopamine receptor agonist, but is not effective for the disruption of the PPI induced by phencyclidine, a glutamine NMDA receptor antagonist, in rats. Furthermore, the ameliorating effect of nicotine is antagonized by methyllycaconitine, a selective $\alpha_{7} \mathrm{nAChR}$ antagonist. The effect of nocitine was also investigated in the stereotyped behavior induced by apomorphine, however, nicotine was found to have no significant effect. Considering these results, the ameliorating effect of the disruption of the PPI via $\alpha_{7} \mathrm{nAChR}$ is therefore thought to be involved in dopaminergic systems. The dopaminergic systems involved in $\alpha_{7} \mathrm{nAChR}$ may be different from the systems involved in stereotypy. In addition, this review describes the effects of the $\alpha_{7}$ nicotinic receptor agonists.
\end{abstract}

Key words $-\alpha_{7}$ nicotinic acetylcholine receptor; schizophrenia; prepulse inhibition; dopamine

\section{1. はじめに}

統合失調症は大別すると，陽性症状，陰性症状, 認知障害からなる多様な症状を呈する精神疾患であ る。その薬物療法に関しては, 定型抗精神病薬 chlorpromazine の創製以降, 陽性症状の改善に大 幅な進歩がみられ，さらにその後, clozapine, olanzapine, risperidone 等の非定型抗精神病薬の登場に より，陰性症状についても改善が図れるようになつ てきた。しかし，認知障害に関しては，統合失調症 患者の多くで認められているにも係わらず，既存の 抗精神病薬ではその改善は十分とは言えない状況で

$a$ 岡山大学大学院医歯薬学総合研究科臨床薬学分野 ( T700-8530 岡山県岡山市津島中 1-1-1), ${ }^{b}$ 愛媛大学 医学部臨床薬理薬剂学教室（T791-0295 愛媛県東温市

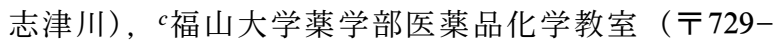
0292 広島県福山市学園町 1-3)

*e-mail: suemaru@m.ehime-u.ac.jp

本総説は, 日本薬学会第 128 年会シンポジウム GS2 で 発表したものを中心に記述したものである.
ある. 認知障害の改善は, 統合失調症患者の社会復 帰，適応のためには重要な課題であり，したがつ て，より優れた認知障害改善作用を有する新たな治 療薬の開発が必要である.

一方, 統合失調症患者では健常人と比較して, 喫 煙者の割合が高いことが知られている．例えば，米 国での調査では，健常人の喫煙率は 25-33\%である のに対し，統合失調症患者の喫煙率は 70-90\%にも のぼる.11) その要因として, nicotine の摂取によ り，統合失調症に伴う注意障害や情報処理障害とい つた認知障害に関連する障害を自ら改善しょうとす る試みを反映していることが推測されている. ${ }^{2,3)}$

\section{PPI 障害モデルにおける Nicotine の障害改善} 作用

われわれは, nicotine の情報処理障害改善作用に 着目し, PPI 障害モデルを用いて, 各種検討を行っ てきた（Figs. 1 and 2)，突然の音刺激による驚愕反 応は，その直前に単独では驚愕反応を示さない程度 


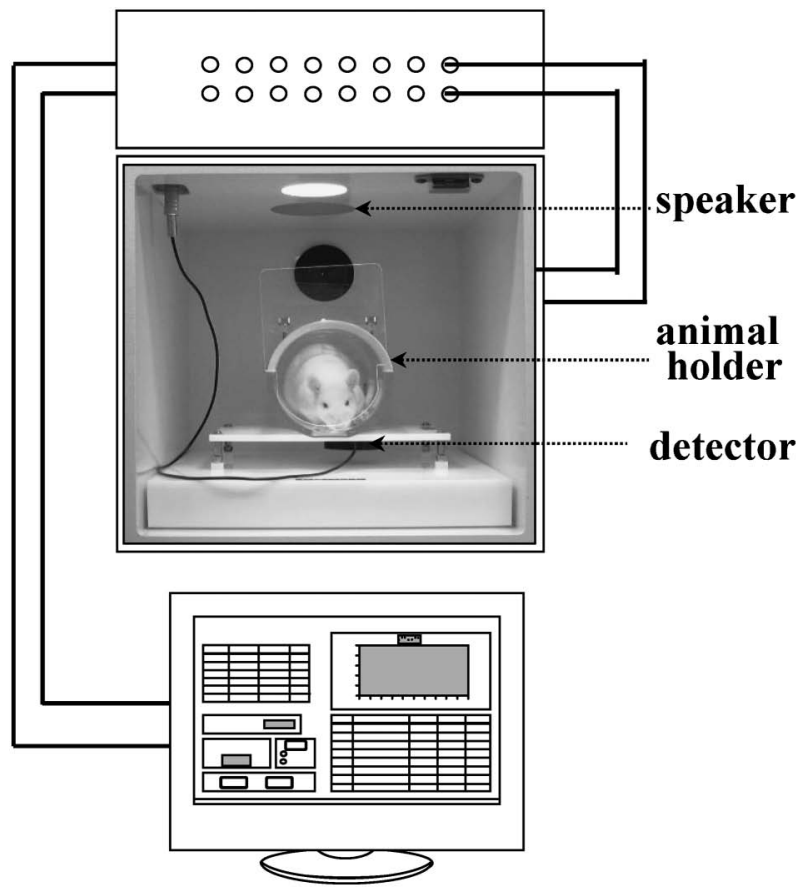

Fig. 1. The Apparatus of the Prepulse Inhibition

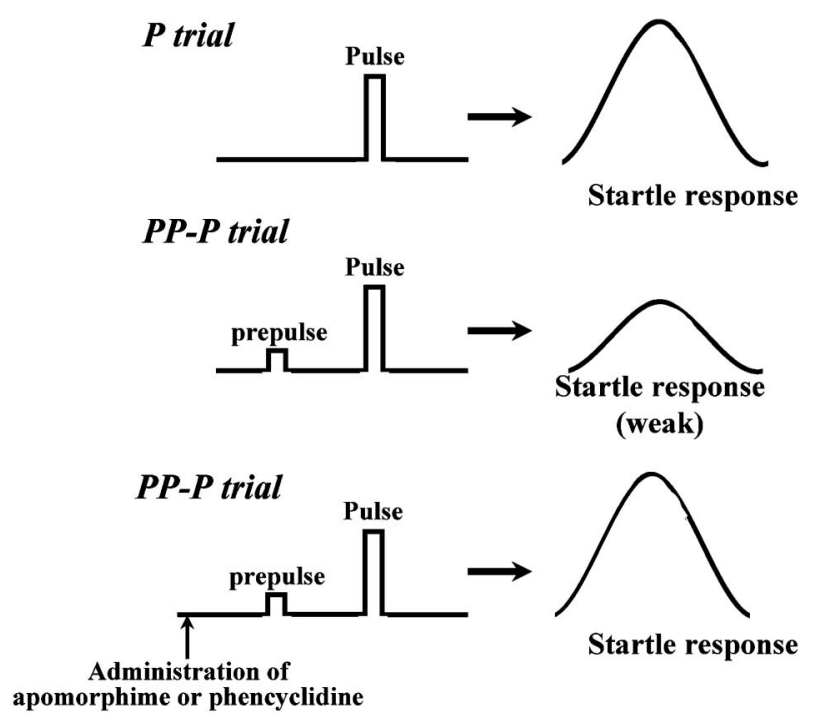

Fig. 2. A Schematic Drawing of the Prepulse Inhibition

の弱い音刺激（prepulse）を与えることにより減弱 する。この現象が prepulse inhibition (PPI) であ る。これは，外界からの感覚入力に対する脳内の ゲーティング機構を反映していると考えられてい る，すなわち，先行する弱い音刺激の情報を得て， 直後の音刺激による情報入力に対し, 無意識に情報 伝達に抑制をかけて驚愕反応に備えていると考えら れている(感覚運動情報制御). 4 ,5)
統合失調症患者では，この感覚運動情報制御，つ まり感覚情報に対する入力制御が失われている結 果, 感覚情報が無分別に入力される. そのため, 統 合失調症患者では常に驚愕反応が惹起される，すな わち, PPI が障害され, 反応の減弱が生じない，統 合失調症の病因仮説としては，ドパミン仮説，グル タミン酸仮説等が提唱されているが，ドパミン受容 体作動薬 apomorphine やグルタミン酸受容体拮抗 薬 phencyclidine (PCP) が，健常人においても統 合失調症様の症状を惹起することが知られている. また，これらの薬物により PPI も障害を受けるこ とが明らかとなっている，その上，ラットやマウス においても，これらの薬物で PPI が障害される. ${ }^{4,5)}$ これらの性質から, PPI 障害モデルは抗精神病作 用，特に情報処理障害の評価系として優れていると 考えられており，広く用いられている。

定型抗精神病薬 haloperidol や非定型抗精神病薬 aripiprazole と同様に, nicotine は apomorphine に より惹起される PPI 障害を用量依存的に改善する ことを見い出した. ${ }^{6,7)}$ この nicotine の PPI 障害改 善作用は $\alpha_{7} \mathrm{nAChR}$ 選択的拮抗薬 methyllycaconitine（MLA）により拮抗されたが， $\alpha_{4} \beta_{2} \mathrm{nAChR}$ 選 択的拮抗薬 dihydro- $\beta$-erythroidine では拮抗されな かった (Fig. 3)。これら一連の実験から, nicotine の PPI 障害改善作用は $\alpha_{7} \mathrm{nAChR}$ を介したもので あることが明らかとなった。 $\alpha_{7} \mathrm{nAChR}$ と統合失調 症の関与については, 統合失調症患者の死後脳を用 いた解析で，同受容体の発現が低下していることが 報告されている。 ${ }^{8)}$ また, nicotine や ACh に対する 親和性が低い変異型 $\alpha_{7} \mathrm{nAChR}$ の存在も知られて いるが，統合失調症患者の中にこの変異型の発現が みられる症例が報告されており，このことも $\alpha_{7}$ $\mathrm{nACh}$ の機能低下と病因との関与を示唆している. 一方，PCP により惹起される PPI 障害に対しては, nicotine は改善作用を示さなかった。これらの検討 結果と統合失調症の成因仮説から考えると, nicotine の抗精神病作用はドパミン神経系と関与してい ると推測される.

われわれは，非定型抗精神病薬 aripiprazole につ いても，PPI 障害モデルを用いて薬効評価を行って いる. Aripiprazole は nicotine の検討結果と同様に, apomorphine により惹起されるPPI 障害について は改善作用を示したが，PCPにより惹起される 


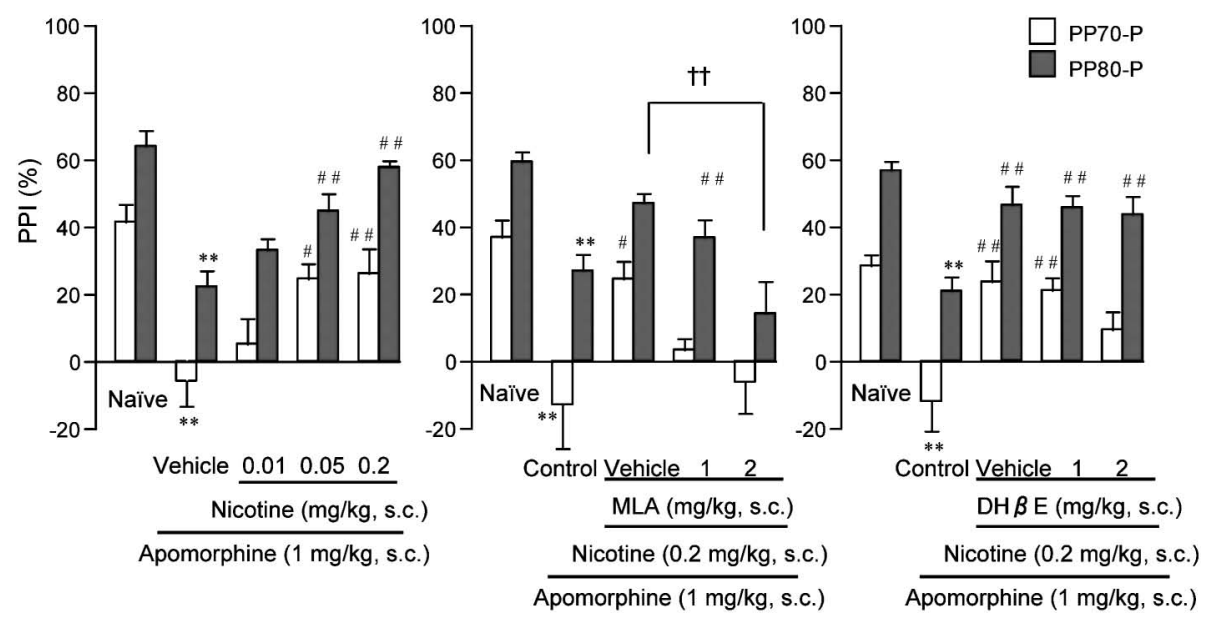

Fig. 3. The Effects of Nicotine on Apomorphine-induced Disruption of the Prepulse Inhibition ${ }^{6}$

${ }^{* *} p<0.01$ compared with the naive group (two-way ANOVA followed by Student's $t$-test). ${ }^{*} p<0.05$, ${ }^{\sharp \sharp} p<0.01$ compared with the apomorphine-alone group (two-way ANOVA followed by Dunnett's test). ${ }^{* \dagger} p<0.01$ compared with the apomorphine + nicotine group (two-way ANOVA followed by Dunnett's test or Student's $t$-test). MLA: methyllycaconitine DH $\beta$ E: dihydro- $\beta$-erythroidine.

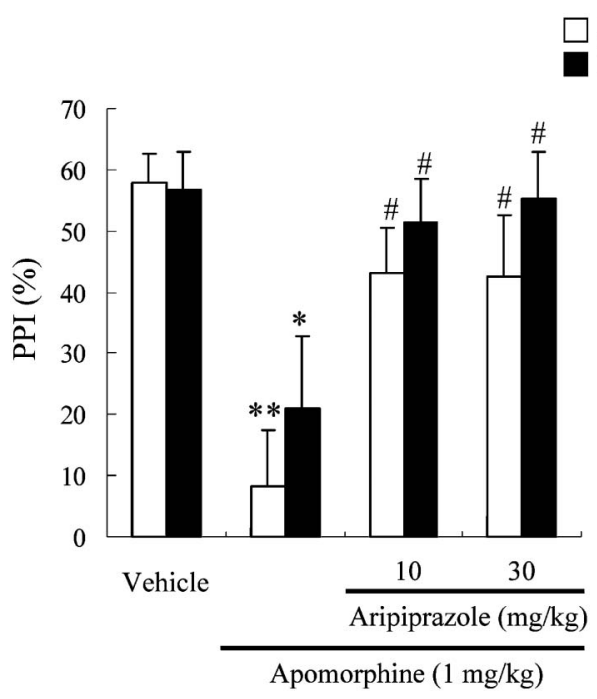

Fig. 4. The Effects of Aripiprazole on the Disruption of the Prepulse inhibition Induced by Apomorphine or Phencycli$\operatorname{dine}^{7)}$

${ }^{*} p<0.05,{ }^{* *} p<0.01$ compared with vehicle group (Student's $t$-test). ${ }^{*} p$ $<0.05$ compared with apomorphine-alone group (two-way ANOVA followed by Dunnett's test)

PPI 障害に対しては，改善作用を示さなかった (Fig. 4).7) Aripiprazole はドパミン，セロトニン受 容体に対して親和性を有しているが，中でもドパミ ン $\mathrm{D}_{2}$ 受容体に対する作用がその抗精神病作用に最 も寄与していると考えられている. 9,10) その機序と しては, 既存の抗精神病薬が有するドパミン $\mathrm{D}_{2}$ 受 容体遮断作用とは異なり, aripiprazole がドパミン 受容体に対して部分作動薬として作用し，ドパミン
神経系を安定化させる薬理学的特性が明らかになつ ている。しかし, nicotine はドパミン受容体に対し て直接的に遮断又は安定化させる機序は明らかにな つていないことから， nicotine が PPI 障害改善作用 に関して抗精神病薬と相似するプロファイルを示し たことは大変興味深い.したがって，今後 nicotine のドパミン神経系を介した抗精神病作用の機序を検 討する必要がある.

\section{PPI 障害モデルにおける Tropisetron の障害} 改善作用

制吐薬として用いられているセロトニン受容体 3 型 $\left(5-\mathrm{HT}_{3}\right)$ 受容体拮抗薬である tropisetron が, 近 年, $\alpha_{7} \mathrm{nAChR}$ の部分作動薬でもあることが報告さ れた。 ${ }^{11,12)}$ 統合失調症患者が好む喫煙には多くの弊 害もあり，当然ながら喫煙は統合失調症の治療とし て理想的であるとは言えない。 Nicotine 自体も nAChR サブタイプに対して, 非選択的である上, 依存性や副作用等の問題がある。それに比して, tropisetron は臨床上での安全性が既に担保されて おり，副作用も少なく，かつ，依存性も有さない点 で，統合失調症治療薬としてより理想的であると考 えられる。

Tropisetron が PPI 障害改善作用を有するか否か を検討したところ， apomorphineにより惹起され るPPI 障害を用量依存的に改善した。さらに，そ の PPI 障害改善作用は $\alpha_{7} \mathrm{nAChR}$ 選択的拮抗薬 MLA により拮抗された。しかし， $\alpha_{7} \mathrm{nAChR} に は$ 親 
和性を有さない $5-\mathrm{HT}_{3}$ 受容体拮抗薬 ondansetron ${ }^{11}$ は，脳血流関門の通過は認められるが，PPI 障害を 改善しなかった。したがって, tropisetronのPPI

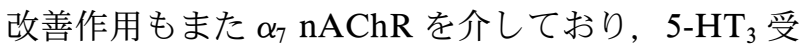
容体を介するものではないと考えられる. Tropisetron は高濃度では，他の nAChR サブタイプに対し ても親和性を有することが報告されているが，今回 検討した用量では他の nAChR サブタイプの関与の 可能性は低いと思われる. ${ }^{12)}$ 一方，PCP により惹 起される PPI 障害に対しては， tropisetron も nicotine と同様に改善作用を示さなかった。 Nicotine を 用いた検討結果との整合性からも， tropisetron と nicotine の PPI 改善作用は同じ作用メカニズムを介 していると考えられる.

以上の結果から, tropisetron が制吐薬としてだ けでなく, 統合失調症に伴う認知障害・情報処理障 害の改善薬となり得る可能性が示された.

\section{4. 常同行動に対する作用の検討}

次に, nicotine や tropisetron が, 統合失調症のそ の他の症状に対しても有効であるか否かを検討する ため，陽性症状と関連の深い現象である apomorphine 誘発性常同行動に対する作用を検討した。し かしながら, nicotine, tropisetron ともに，常同行 動を抑制する傾向は見受けられたものの，有意な抑 制作用は示さなかつた。前述の通り， nicotine や tropisetronの抗精神病作用は，ドパミン神経系と 関与していると考えられるが，同様にドパミン神経 系の関与が深いと考えられている常同行動に対して は，有意な抑制作用を示さなかった。この点では， $\alpha_{7} \mathrm{nAChR}$ を介した抗精神病作用は， $\mathrm{D}_{2}$ 受容体拮 抗作用を有し，PPI 障害改善作用の夕ならず，常同 行動にも抑制作用を示す aripiprazole 等とは異なつ ている. ${ }^{7)}$ この相違の原因の 1 つとして考えられる ことは, tropisetron が $\alpha_{7} \mathrm{nAChR}$ の部分作動薬で あるということである.1112) すなわち, tropisetron を用いた場合では， $\alpha_{7} \mathrm{nAChR}$ を介する作用が部分 的にしか発揮されていない可能性が考えられる。も し，完全作動薬を用いれば，常同行動に対しても有 意な抑制作用を示すかもしれない。しかしながら， nicotine は nAChR サブタイプに対して選択性を持 たないため，高用量で有効性を判断するのは困難で あろう。したがって， $\alpha_{7} \mathrm{nAChR}$ に選択性の高い薬 物を用いた場合，統合失調症の陽性症状に有効性を
示す可能性が高い.さらなる検討の必要があると思 われる。一方，ドパミン神経系のうち，陽性症状と 関与している経路と，認知障害や情報処理障害と関 与している経路とが異なっている可能性が考えられ る。ドパミン神経系の中で統合失調症との関与が明 らかになっている経路としては，中脳辺縁系，中脳 皮質系が挙げられる。このうち陽性症状に関して は，中脳辺縁系の関与について多くの報告がなされ ており，その信憑性は高い。しかし，認知・情報処 理障害に関しては，中脳辺縁系，中脳皮質系いずれ の関与を示唆する報告もあり，いまだに判然として いない. 今後の研究課題である.

\section{5. おわりに}

今回の検討結果により， $\alpha_{7} \mathrm{nAChR}$ が統合失調症 の治療ターゲットとなり得る可能性が示された. 既 存の抗精神病薬に加えて, tropisetronを認知障 害・情報処理障害改善薬として用いるという手段, さらには， $\alpha_{7} \mathrm{nAChR}$ フルアゴニスト活性を有する 新規抗精神病薬の開発の有望性が，本研究により示 唆された.

謝辞本研究に際し, phencyclindine の原末を 合成・提供下さいました福山大学の町支臣成先生並 びに日比野俐先生に深く感謝申し上げます。

\section{REFERENCES}

1) Dursun S. M., Kutcher S., Med. Hypotheses, 52, 101-109 (1999).

2) Dalack G. W., Healy D. J., Meador-Woodruff J. H., Am. J. Psychiatry, 155, 1490-1501 (1998).

3) Glassman A. H., Am. J. Psychiatry, 150, 546553 (1993).

4) Geyer M. A., Krebs-Thomson K., Braff D. L., Swerdlow N. R., Psychopharmacology (Berl), 156, 117-154 (2001).

5) Geyer M. A., Ellenbroek B., Prog. Neuropsychopharmacol. Biol. Psychiatry, 27, 10711079 (2003).

6) Suemaru K., Yasuda K., Umeda K., Araki H., Shibata K., Choshi T., Hibino S., Gomita Y., Br. J. Pharmacol., 142, 843-850 (2004).

7) Kohnomi S., Suemaru K., Kawasaki H., Araki H., J. Pharmacol. Sci., 106, 645-650 (2008).

8) Freedman R., Hall M., Adler L. E., Leonard 
S., Biol. Psychiatry, 38, 22-33 (1995).

9) Kikuchi T., Tottori K., Uwahodo Y., Hirose T., Miwa T., Oshiro Y., Morita S., J. Pharmacol. Exp. Ther., 274, 329-336 (1995).

10) Shapiro D. A., Renock S., Arrington E., Chiodo L. A., Liu L.-X., Sibley D. R., Roth B. L., Mailman R., Neuropsychopharmacology, 28, 1400-1411 (2003).
11) Macor J. E., Gurley D., Lanthorn T., Loch J., Mack R. A., Mullen G., Tran O., Wright N., Gordon J. C., Bioorg. Med. Chem. Lett., 11, 319-321 (2001).

12) Papke R. L., Porter-Papke J. K., Rose G. M., Bioorg. Med. Chem. Lett., 14, 1849-1853 (2004). 